\title{
Cytotoxicity Test of Isolated Compound from Syzygium malaccense Stem Bark on Fibroblast BHK 21 Cells
}

\author{
Mahdania Ratri Paramitha, Tukiran* \\ Chemistry Department \\ Faculty of Mathematics and Naturals Sciences \\ Universitas Negeri Surabaya \\ Surabaya, Indonesia \\ tukiran@unesa.ac.id
}

\begin{abstract}
Medicinal plants are one of the traditional medicines that are now often used by the community. One plant that can be used as a medicinal plant is guava (Syzygium malaccense). The plant is a Syzygium genus that grows a lot in Java. Several studies have shown that stem bark of the plant contain sapiens, alkaloids, lycopene, ascorbic acid, beta carotene, and the most dominated by tannins which are antibacterial and antifungal. The objective of research: to prove the cytotoxicity test of isolated dichloromethane extract of guava (Syzygium malaccense) stem barks with a concentration of $12.5 \%, 25 \%, 50 \%$ and $100 \%$ of baby hamster kidney fibroblasts cell culture (BHK 21). Methods and materials: laboratory experimental research with Post Test Only using 6 treatments. research in the form of fibroblast BHK 21 cell culture as many as 6 groups, namely given isolated dichloromethane extract of Syzygium malaccense stem bark $12.5 \%$, isolated dichloromethane extract of Syzygium Malaccans stem bark 25\%, isolated dichloromethane extract of Syzygium malaccense stem bark $50 \%$, and isolated dichloromethane extract of Syzygium malaccense stem bark $100 \%$, cell control and media control. The research stages include BHK cell split stages and treatment stages. The reading results using Elisa Reader. Percentage of living cells using the Freshney formula). The results of the study: isolated dichloromethane extract of Syzygium malaccense stem bark $12.5 \%$ concentration had $79 \%$, isolated dichloromethane extract of Syzygium malaccense stem bark $25 \%$ concentration had $77 \%$ live cells, $\mathbf{5 0 \%}$ concentration had $\mathbf{7 5 \%}$ live cells, and $100 \%$ concentration had $72 \%$ live cells. Conclusion: isolated dichloromethane extract of Syzygium malaccense stem bark $12.5 \%, 25 \%, 50 \%$ and $100 \%$ concentration not toxic to BHK 21 fibroblast cells.
\end{abstract}

Keywords—cytotoxicity, Syzygium malaccense, BHK21

\section{INTRODUCTION}

Medicinal plants are one of the traditional medicines that are now often used by the community. One plant that can be used as a medicinal plant is guava (Syzygium malaccense). The plant is a Syzygium genus that grows a lot in Java. Several studies have shown that stem bark of the plant contain saponins, alkaloids, lycopene, ascorbic acid, beta carotene, and the most dominated by tannins which are antibacterial and antifungal.

Syzygium malaccense (syn. Eugenia malaccensis, Jambos malaccensis) is one of the Myrtaceae families. This plant is native to Malaysia and India, commonly known as Malay Apple [1]. Several studies have been carried out on this plant, one of which is methanol extract leaves of Syzygium malaccense have effective antimicrobial activity on Candida albicans and Proteus bacteria [2]. Ethanol extract of guava leaf can also limit the growth of Streptococcus mutans bacteria with a value of Minimum Inhibitory Concentration (MIC) of $2 \%$ and an inhibitory area diameter of $12.73 \mathrm{~nm}$ [3]. In the stem bark, cashew nuts also have a variety of biological activities, namely as antivirus, antibacterial and antifungal. This plant is also used in traditional medicine for the treatment of infectious diseases [4].

This natural material empirically in the community does not because toxic effects, but scientific research has not been carried out to prove that this natural material is nontoxic. This causes the cytotoxicity test of isolates of dichloromethane extract Syzygium malaccense stem bark in vitro before research on experimental animals and humans. Based on this background, a research was conducted on the cytotoxicity test of isolated compound from dichloromethane extracts Syzygium malaccense stem bark on fibroblast Baby Hamster Kidney-21 (BHK-21) cells.

\section{MATERIALS AND METHODS}

\section{A. Materials}

Materials used in this research are stem bark of Syzygium malaccense, methanol, hexane, dichloromethane, ethyl acetate, BHK 21 cells, trypsin versene solution, D-MEM media , $10 \%$ fetal bovine serum albumin, MTT reagent, PBS, DMSO.

\section{B. Extraction}

The stem bark of Syzygium malaccense was collected from Gondang Manis, Bandar Kedungmulyo, Jombang, East Java, Indonesia. The sample was washed with water, then dried overnight. It was dried and ground. Dried stem bark was macerated with methanol then partitioned with hexane and dichloromethane, respectively. Dichloromethane fraction was evaporated to dryness in a vacuum rotary evaporator.

\section{Isolation}

The dichloromethane extract of stem bark of Syzygium malaccense was isolated with some chromatographic techniques using hexane : ethyl acetate $(5: 1)$ as eluent. The works were conducted repeatedly to obtain pure isolate. The isolate was then identified with FTIR spectrophotometry. 


\section{Cytotoxicity Test}

Baby Hamster Kidney (BHK-21) cells were cultivated in a roux bottle and harvested with trypsin versene solution. BHK-21 cells were put into each 96 wells microplate that has added D-MEM media which contain $10 \%$ fetal bovine serum albumin and incubated in $37^{\circ} \mathrm{C}$ for 24 hours. Isolated compound was added into 96 microplate wells with concentration $12.5 \%, 25 \%, 50 \%$ and $100 \%$. Microplate well was incubated for 24 hours and after 24 hours, each well that will be read were added by solution containing MTT reagent in PBS, then re-incubated for 4 hours. Furthermore, each well was added with DMSO and shaken with plate shaker. The wells would be read at Elisa Reader in 620 wavelength. Percentage of the live cells was calculated by formula (1), according to experimental study [5].

$$
\% \text { Live Cells }=\frac{\text { Test Group }+ \text { Media }}{\text { Cells }+ \text { Media }} \times 100 \%
$$

Information:

- $\%$ live cells : formazan value of OD (Optical Density) for each sample

- Test group: formazan value of OD (Optical Density) after each test

- Media: formazan value of OD (Optical Density) on the average of each media control

- Cell: formazan value of OD (Optical Density) on average of cell control

- The calculation results are said to be non-toxic if $\geqslant 60 \%$ of cells live.

\section{RESULT AND DISCUSSION}

Cytotoxicity test is an important initial stage test for a new material that will be used in the field of dentistry. This test is done to find out whether the material is toxic or not. In this study, cytotoxicity test was carried out by testing isolates in vitro on cell culture [5].

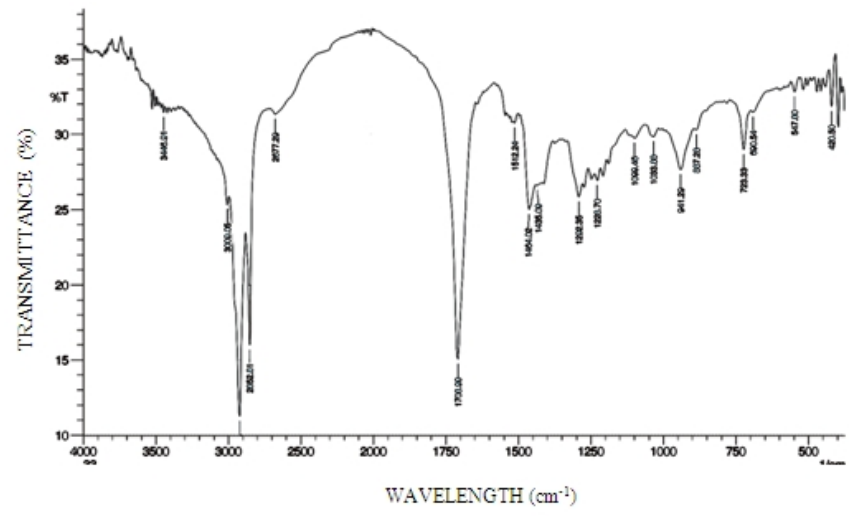

Fig 1. FT-IR spectrum of isolated compound of $S$.malaccense

Isolate $\mathrm{X}$ used in this study is the result of isolation from dichloromethane extract using vacuum liquid chromatography using hexane: ethyl acetate $(5: 1)$ eluent. Then identified using an IR spectrophotometer. Based on the IR spectrum in figure 1. Shows a sharp absorption in the area of $1708 \mathrm{~cm}^{-1}$ indicating the presence of a group $\mathrm{C}=\mathrm{O}$. the presence of carboxylic acid $\mathrm{OH}$ groups is indicated by the widened band between 3000-2400 $\mathrm{cm}^{-1}$. Absorption bands in the area of $3000-2700 \mathrm{~cm}^{-1}$ which overlap with the absorption of $\mathrm{OH}$ groups are alkyl $\mathrm{C}-\mathrm{H}$ stretch vibrations. From the IR spectrum data shows that the isolated $\mathrm{X}$ compounds are acidic.

This study used a culture of BHK-21 fibroblast cells derived from hamster baby kidney fibroblasts. The use of fibroblast cells because fibroblast cells are the largest cell in connective tissue and is often used to test cytotoxicity in the field of dentistry [6]. BHK 21 fibroblast cells are easy to grow and sub-culture, have stable properties, have mutations and structural peculiarities with human fibroblast cells which are commonly found in the oral cavity [7].

In this study, Cytotoxicity tests used the MTT assay method. MTT assay testing method is one of the common methods that can be used to determine the toxic effects of an ingredient. The use of this assay is because this method is relatively fast, sensitive, accurate, and can be used to measure large samples Cytotoxicity testing with the MTT assay used certainly MTT reagent [3-(4,5-dimethyltiazol-2-yl)-2,5dipheniltetrazolium bromide] which is a yellow tetrazolium salt which is insoluble in water.

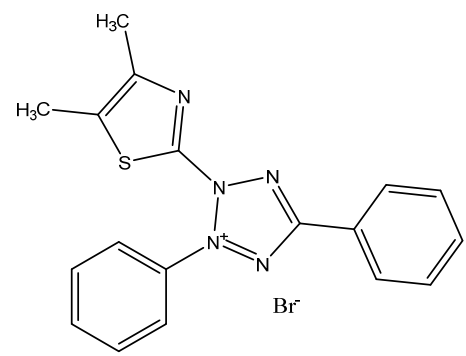

Fig 2. Molecular Structure of MTT [-2-yl)-2,5-difeniltetrazolium bromide [8].

Whereas, dead cells will not be affected by MTT reagent because the mitochondrion does not aspire so that the dehydrogenase enzyme is inactive due to the cytotoxic effect of the material which causes the tetrazolium ring to be unbroken so formazan will not form which gives a purple color, but the color remains yellow [9]. Result measurement is done using the Elisa Reader tool. The greater the absorbance shows the more number of cells that live $[7 ; 10]$. In this study, data obtained from the calculation of live cells percentage from cytotoxicity test using MTT assay using BHK-21 cells (TABLE 1).

TABLE I. PERCENTAGE OF LIVE CELLS BHK 21

\begin{tabular}{|c|c|c|}
\hline $\begin{array}{c}\text { Concentration of isolate } \\
(\%)\end{array}$ & Number of Sample & \% Living cell \\
\hline 12.5 & 8 & 79 \\
\hline 25 & 8 & 77 \\
\hline 50 & 8 & 75 \\
\hline 100 & 8 & 72 \\
\hline Control cell & 8 & 100 \\
\hline Control media & 8 & 0 \\
\hline
\end{tabular}

The results of cytotoxicity test of isolate on fibroblast BHK-21 cells showed that an isolated dichloromethane extract of Syzygium malaccense stem bark $12.5 \%$ 
concentration had $79 \%$, isolated dichloromethane extract of Syzygium malaccense stem bark $25 \%$ concentration had $77 \%$ live cells, $50 \%$ concentration had $75 \%$ live cells, and $100 \%$ concentration had $72 \%$ live cells.

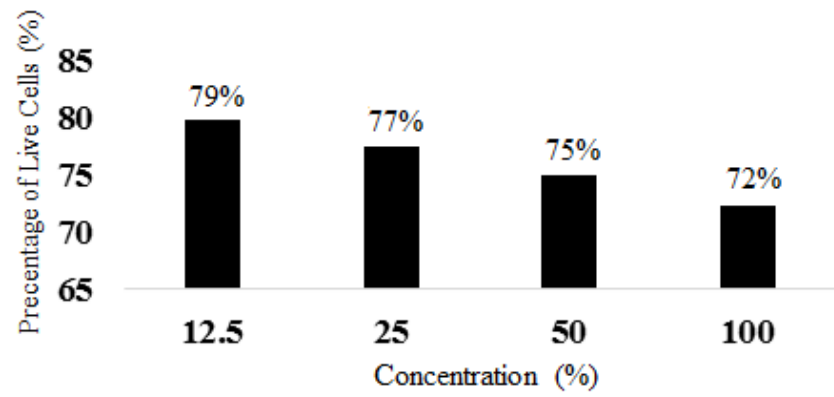

Fig 3. Relationship percentage graph between live cells and concentration

In Fig 3, it was seemed that the percentage of live cells is decreasing along with the increasing concentration of isolated compounds. Based on the calculation of the percentage of cell life, it is known that isolated compounds is said to be not toxic because the percentage of life of cell isolated compound with concentrations of $100 \%, 50 \%, 25 \%$ and $12.5 \%$ are greater than $60 \%$.

\section{CONCLUSION}

Isolated dichloromethane extract of Syzygium malaccense stem bark $12.5 \%, 25 \%, 50 \%$ and $100 \%$ concentration not toxic to BHK 21 fibroblast cells

\section{REFERENCES}

[1] Bavani, Arumgam., et al. "Antioxidant and Antiglycemic Potentials of a Standardized Extract of Syzygium malaccense". LWT-Food Science and Technology, 2014, Vol 59. No 2. pp 707-712.
[2] Aiswarya, Purushothaman, et al. "A Study on Antimicrobial and Anthelmintic Activity of Methanolic Leaf Extracts of Syzygium malaccense (L.) Merr. \& Perry". Journal of Chemical and Pharmaceutical Research, 2015, Vol 7. No 4. pp 838-841.

[3] Eka, Ariayani Hermawati. "Formulation of Dental Gel Preparation Contains Guava (Syzygium malaccense) Ethanol Leaf Extract as Streptococcus mutans Inhibitor of Bacterial Growth". (Formulasi Sediaan Gel Gigi yang Mengandung Eksrak Etanol Daun Jambu Bol (Syzygium malaccense) Sebagai Penghambat Pertumbuhan Bakteri Streptococcus mutans). 2016. Universitas Garut, Garut. "unpublished thesis"

[4] Locher, C.P., et al. "Anti-microbial activity and anti-complement activity of extracts obtained from selected Hawaiian medicinal plants". Journal of ethnopharmacology. 1995. Vol 49. No 1. pp 23-32.

[5] Ma'at, S. Teknik Dasar Kultur Sel. Surabaya: Airlangga University press, 2011.

[6] Kartika, Chyntya G. Dian, Mulawarmanti., M., Fanny Laihad. Cytotoxicity of Avicena marine leaf Extract Against Fibroblast Cells. Denta Journal, 2014, Vol 8. No 2. pp 67-76.

[7] Christian, Khoswanto., Ester, Arijani., Pratiwi, Soesilawati. "Cytotoxicity test of 40, 50 and 60\% Citric Acid as Dentin Conditioner by using MTT Assay on Culture Cell line". J. Dent, 2008, Vol 41. No 3. pp 103-106.

[8] C., Juan Stockert., et al. "MTT Assay for Cell Viability: Intracellular Localization of The Formazan Product is in Lipid Droplets". Acta Histochemica. 2012, Vol 114, No 8. pp 785-796.

[9] Andi, Suhendi., et al. "Determination of Antioxidant Activity of Extract Polar and Semipolar Fraction of Cynometra ramiflora Linn using DPPH Assay". Acta Pharmacie Indonesia, 2013, Vol 1. No 1. pp 22-25.

[10] Karunia, N. R., Elly, M., Soebagio. "Cytotoxicity Test of Rind Extracts and Kelengkeng Fruit Seeds (Euphoria Longana Lam.) On Fibroblast Cells with MTT Assay". (Uji Sitotoksisitas Ekstrak Kulit dan Biji Buah Kelengkeng (Euphoria Longana Lam.) terhadap Sel Fibroblas dengan MTT Assay). Material Dental Journal, 2014, Vol 5. No 1. pp 31-35. 